\title{
UJI PATOGENISITAS NEMATODA PATOGEN SERANGGA (Steinernema carpocapsae) DARI TANAH GAMBUT TERHADAP RAYAP TANAH (Coptotermes curvignathus)
}

\author{
PATOGENICITY TEST OF SERANGGA PATHOGENIC NEMATODES (Steinernema \\ carpocapsae) FROM PEAT LAND TOWARDS LAND TERM (Coptotermes curvignathus)
}

\author{
Ari Paster, Indri Hendarti, dan Tris Haris Ramadhan \\ Program Studi Agroteknologi Fakultas Pertanian Universitas Tanjungpura \\ Jln. Prof. Dr. Hadari Nawawi, Pontianak, 78124, Indonesia.
}

\begin{abstract}
ABSTRAK
Rayap tanah (Coptotermes curvignathus) merupakan salah satu hama yang menimbulkan kerugian ekonomis yang sangat besar karena banyak menyerang tanaman pertanian sehingga menyebabkan tanaman mati dan produksi menurun. Salah satu cara pengendalian yaitu secara biologis menggunakan nematoda patogen serangga (Steinernema carpocapsae). Penelitian ini bertujuan untuk melihat daya patogenisitas $S$. carpocapsae dari isolat tanah gambut terhadap rayap tanah (C. curvignathus). Penelitian dilaksanakan di Laboratorium Hama Tumbuhan, Fakultas Pertanian, Universitas Tanjungpura Pontianak. Rancangan yang digunakan Rancangan acak kelompok (RAK) dengan menggunakan satu perlakuan dan 6 taraf konsentrasi $S$. carpocapsae $(25 \mathrm{ji} / \mathrm{ml}, 50 \mathrm{ji} / \mathrm{ml}, 100 \mathrm{ji} / \mathrm{ml}, 200$ $\mathrm{ji} / \mathrm{ml}, 400 \mathrm{ji} / \mathrm{ml}$, dan $800 \mathrm{ji} / \mathrm{ml}$ ) dengan $5 \mathrm{kali}$ pengulangan. Pengujian patogenisitas dilakukan terhadap C. curvignathus kasta pekerja. Kemampuan patogenisitas $S$. carpocapsae diukur berdasarkan mortalitas, jumlah $S$. carpocapsae yang keluar, periode letal dan virulensi. Hasil pengujian menunjukan bahwa $S$. carpocapsae mampu menyebabkan mortalitas sebesar $100 \%$ pada perlakuan $800 \mathrm{ji} / \mathrm{ml}$ dalam 96 jam setelah inokulasi. Priode letal yang dihasilkan sebesar 40,68 dan Virulensi sebesar 0,024. Jumlah $S$. carpocapsae yang dihasilkan tidak berbeda nyata antara satu perlakuan dengan perlakuan lainnya dikarenakan $C$. curvignathus merupakan serangga uji yang memiliki tubuh ukuran kecil antara 4,5-5,0 $\mathrm{mm}$. Sehingga tiap perlakuan konsentrasi $S$. carpocapsae yang diinokulasikan memiliki kapasitas ruang yang sama untuk perkembangannya.
\end{abstract}

Kata kunci : Inokulasi, Mortalitas, Priode letal, Virulensi

\begin{abstract}
Subterranean termites (Coptotermes curvignathus) is one of the pests which caused disadvantages economically. They attacked on agricultural plant and the production will be declined. Biological control was done by used. Steinernema carpocapsae to reduce population of insect. The aim of the research is to study about pathogenicity of nematode $S$. carpocapsae isolated from peat soil against subterranean termites $(C$. curvignathus). This research was conducted in the Laboratory of Plant Pests, Faculty of Agriculture, University of Tanjungpura Pontianak. This research was using randomized block design (RAK) with 1 treatment and 6 factor of concentration S. carpocapsae $(25 \mathrm{ji} / \mathrm{ml}, 50 \mathrm{ji} / \mathrm{ml}, 100 \mathrm{ji} / \mathrm{ml}, 200 \mathrm{ji} / \mathrm{ml}, 400 \mathrm{ji} /$ $\mathrm{ml}$, and $800 \mathrm{ji} / \mathrm{ml}$ ) with 5 repetitions. Pathogenicity test conducted on C. curvignathus workers. The pathogenicity of $S$. carpocapsae measured by mortality level, the number of $S$. carpocapsae emerged from the insect, lethal period and virulence. The results showed that S. carpocapsae caused $100 \%$ mortality in $800 \mathrm{ji} /$ $\mathrm{ml}$ treatment, after 96 hours inoculation. Lethal period generated is 40.68 and virulence 0,024. The ammount of $S$. carpocapsae emerged is not significantly different between one treatment with another treatments due to the small size of $C$. curvignathus body. The body size of $C$. curvignathus is between 4.5 to $5.0 \mathrm{~mm}$. So each treatment of concentration of $S$. carpocapsae has the similar space capacity for its development.
\end{abstract}

Keywords : Inoculation, mortality, Lethal period, Virulence 


\section{PENDAHULUAN}

Rayap tanah (Coptotermes curvignathus Holmgren) merupakan salah satu hama yang tergolong dalam ordo Isoptera. Hama ini bersifat polifag, hidup secara berkelompok, banyak menyerang tanaman perkebunan dan tanaman tahunan seperti karet, sawit, mangga, coklat, alpokat, nangka, durian, teh, kina, kayu jati,sengon pinus, randu, dan kapas (Ridwanti, 2002). Perluasan areal perkebunan dan pemukiman menyebabkan habitat rayap di alam menjadi terganggu, ketersediaan tanaman yang sudah mati kering sebagai makanan rayap berkurang sehingga rayap menyerang tanaman perkebunan dan tanaman tahunan untuk bahan bangunan serta industri. Kerugian yang ditimbulkan mencapai 1,2 triliun rupiah pertahun (Mahardika, 2001). Tingginya tingkat serangan rayap pada tanaman perkebunan, bangunan dan industri mengharuskan dilakukan tindakan pengendalian yang tepat dan ramah lingkungan.

Berbagai upaya telah dilakukan dalam pengendalian rayap, salah satunya dengan penggunaan bahan kimia. Pengendalian secara kimia yang dilakukan memberikan efek negatif terhadap lingkungan dan penggunanya. Lingkungan menjadi tercemar bahan kimia dan terjadi gejala keracunan terhadap manusia. Oleh karena itu, alternatif pengendalian yang tepat dan ramah lingkungan sangat diperlukan. Salah satu alternatif yang dapat diberikan yaitu dengan pemanfaatan agens pengendali hayati Nematoda Patogen Serangga (NPS).

NPS merupakan salah satu agens pengendali hayati yang potensinya sangat besar untuk dikembangkan. Potensinya yang besar dalam kemampuan mencari inang dan membunuh hama sasaran menyebabkan agens pengendali hayati ini banyak dikulturkan (Rosman et al.,1998). NPS memiliki sifat bersimbiosis mutualisme dengan bakteri Xenorhabdus yang juga patogenik terhadap serangga inang (Kaya dan Gaugler, 1990; Tanada dan Kaya, 1993).

Kalimantan Barat merupakan wilayah yang sebagian besar berdataran rendah dan memiliki areal tanah gambut yang cukup luas.
Kondisi geologis lahan gambut dan kondisi klimatisnya yang unik diyakini sangat besar pengaruhnya terhadap karakteristik biota yang ada. Karakterisitik yang ada meliputi patogenpatogen yang dapat menyerang serangga atau yang sering disebut entomopatogen.

Jenis-jenis entomopatogen yang ditemukan tidak berbeda dengan jenis di lokasi lain. Namun demikian, dengan karakteristik faktor fisik setempat yang khas tidak tertutup kemungkinan terjadinya tingkat patogenisitas dan virulensi yang berbeda. Dalam kaitannya dengan hal tersebut, maka perlunya dilakukan uji patogenisitas.

\section{BAHAN DAN METODE}

Penelitian dilakukan di Laboratorium Hama Tumbuhan, Fakultas Pertanian, Universitas Tanjungpura, Pontianak pada bulan oktober 2015 sampai bulan februari 2016. Penelitian menggunakan rancangan acak kelompok (RAK) dengan satu perlakuan dan 6 taraf konsentrasi $S$. carpocapsae yang diulang sebanyak 5 kali. Konsentrasi yang digunakan meliputi $25 \mathrm{ji} / \mathrm{ml}, 50$ $\mathrm{ji} / \mathrm{ml}, 100 \mathrm{ji} / \mathrm{ml}, 200 \mathrm{ji} / \mathrm{ml}, 400 \mathrm{ji} / \mathrm{ml}$, dan 800 $\mathrm{ji} / \mathrm{ml}$.

Pengujian patogenisitas $S$. carpocapsae dilakukan terhadap rayap kasta pekerja. Isolat $S$. carpocapsae yang digunakan merupakan hasil perbanyakan koleksi laboratorium hama tumbuhan yang diisolasi dari tanah gambut. $S$. carpocapsae dikembangbiakkan secara in vivo menggunakan larva T. molitor sebanyak 20 ekor. Perbanyakan dilakukan pada cawan petri berukuran $14 \mathrm{~cm}$ yang sudah dilapisi kertas saring. Sebelumnya pada kertas saring tersebut sudah diinfestasikan suspensi S. carpocapsae dengan cara meneteskan di permukaan kertas saring. Cawan petri kemudian diinkubasi dalam ruang gelap selama lebih kurang 48 jam. Larva $T$. molitor yang terinfeksi selanjutnya dilakukan proses White trap.

White trap dilakukan dengan menggunakan 2 cawan petri, ukuran $9 \mathrm{~cm}$ yang diletakkan terbalik pada cawan petri berukuran $14 \mathrm{~cm}$. Bagian atas cawan petri yang berukuran 9 
$\mathrm{cm}$ dialasi kertas saring sebagai tempat untuk meletakkan larva T. Molitor yang terinfeksi $S$. carpocapsae. Larva yang terinfeksi diletakkan di atas kertas saring bentuk melingkar dan diinkubasi hingga larva hancur. Aquades dituangkan pada cawan petri besar sampai batas cawan petri berukuran $9 \mathrm{~cm}$. Cawan petri ditutup kembali agar tidak terkontaminasi dan diinkubasi selama 5-6 hari. Nematoda yang terperangkap pada air aquades kemudian dipanen dan disimpan pada gelas Backer. Nematoda yang telah dipanen kemudian disaring dengan saringan 400 mess untuk memperoleh juvenil infektif yang selanjutnya akan digunakan dalam proses pengujian patogenisitas.

Perbanyakan serangga uji dilakukan dalam ember plastik berukuran $(50 \times 100 \mathrm{~cm})$ dan diberi pakan kayu. Bagian bawah ember diisi dengan tanah $20 \mathrm{~cm}$ untuk mengatur kelembabannya. Serangga uji yang digunakan yaitu rayap kasta pekerja yang mempunyai bentuk tubuh seragam dari spesies yang sama, panjang badan untuk rayap kasta pekerja $\pm 5 \mathrm{~mm}$. Selanjutnya disiapkan wadah gelas plastik kecil untuk penyiapan pengujian. Letakkan 20 ekor $C$. curvignathus kedalamnya dan dialasi dengan kertas tissu. Kertas tissu dibasahi dengan air aquades dan atasnya diberi makan $C$. curvignathus dengan kertas kardus. $C$. curvignathus kasta pekerja yang mampu bertahan hidup selanjutnya digunakan untuk pengujian.

Pengujian dilakukan dengan menggunakan metode kertas saring. Cara yang dilakukan yaitu menyiapkan satu lembar kertas saring ukuran 8 $\mathrm{cm}$ pada cawan petri ukuran $9 \mathrm{~cm}$. Suspensi nematoda diteteskan $2 \mathrm{ml}$ pada kertas saring dengan konsentrasi sesuai perlakuan. Setiap cawan petri dimasukkan 20 ekor rayap kasta pekerja. Data dikumpulkan dari pengamatan berikut :

Gejala $C$. curvignathus yang terinfeksi $S$. Carpocapsae. Gejala rayap yang terinfeksi $S$. carpocapsae diamati setiap 12 jam sekali dengan melihat perubahan yang terjadi pada rayap, diantaranya perubahan gerak, aktivitas dan perubahan warna tubuh rayap.
Mortalitas C. Curvignathus. Mortalitas rayap C. curvignathus pada tiap perlakuan diamati setiap 12 jam sekali dan dihitung dengan menggunakan rumus :

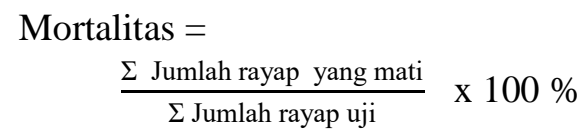

\section{Waktu kematian}

Waktu kematian $C$.curvignathus dihitung mulai dari inokulasi sampai rayap mati pada tiap perlakuan. Selain itu diamati juga periode letal dan virulensinya. Periode letal merupakan lamanya waktu yang dibutuhkan nematoda untuk membunuh serangga uji sedangkan virulensi merupakan tingkat patogenisitas yang diukur oleh banyaknya organisme yang diperlukan untuk menimbulkan penyakit pada jangka waktu tertentu. C. curvignathus yang mati selanjutnya dilakukan White Trap (perangkap putih). Waktu kematian diamati 12 jam sekali dan dicatat pada setiap ulangan. Untuk menentukan periode letal dan virulensi $S$. carpocapsae terhadap serangga uji C. curvignathus digunakan rumus (Susilo., et al., 1993):

$$
\begin{aligned}
& \text { Periode letal : }(\mathbf{T})=\frac{\left[\sum(\mathbf{H i} \mathbf{x} \mathbf{M i})\right]}{\left[\sum(\mathbf{M i})\right]} \\
& \text { Virulensi : } \quad(\boldsymbol{\delta})=\mathbf{1} / \mathbf{T} \\
& \text { Keterangan : } \\
& \mathrm{H}_{\mathrm{i}}=\text { Hari ke-i terjadinya kematian } \\
& \mathrm{M}_{\mathrm{i}}=\text { Jumlah serangga uji yang mati pada } \\
& \quad \text { hari ke-i }
\end{aligned}
$$

Jumlah nematoda yang keluar dari tubuh C. Curvignathus. Jumlah nematoda yang keluar dari tubuh $C$. curvignathus dapat diketahui dengan cara white trap. Hasil white trap selanjutnya dimasukkan ke dalam gelas dengan volume tertentu. Kemudian suspensi diambil sebanyak $1 \mathrm{ml}$ dan diteteskan pada cawan petri yang telah diberi garis 16 kotak. Perhitungan dilakukan dengan mikroskop dan diulang sebanyak $10 \mathrm{x}$. Adapun rumus perhitungan yang digunakan yakni :

$$
N P S=\frac{\alpha x V}{n}
$$


Keterangan :

NPS : jumlah nematoda

$\alpha \quad$ : rerata nematoda/ml (dari perhitungan sampel)

$\mathrm{V} \quad$ : volume air dalam petri

$n \quad$ : jumlah serangga uji yang di white trap

\section{HASIL DAN PEMBAHASAN}

Gejala Coptotermes curvignathus Holmgren yang terinfeksi Steinernema carpocapsae

C. curvignathus yang terinfeksi NPS menunjukan beberapa gejala, diantaranya yaitu gerakannya menjadi lambat, bila disentuh tidak menunjukan respon seperti $C$. curvignathus sehat lainnya. C. curvignathus yang terinfeksi NPS tubuhnya menjadi lembek dan terjadi pembengkakan pada bagian abdomennya. Bila $C$. curvignathus ditekan maka akan mengeluarkan cairan berwarna putih kekuningan dan berbau busuk.

Bagian tubuh $C$. curvignathus yang terinfeksi NPS menunjukan gejala perubahan warna, makin lama tubuh rayap akan menjadi hitam kecoklatan dibagian seluruh tubuhnya. Perubahan warna tubuh rayap dimulai dari bagian kepala hingga menyeluruh dari bagian tubuh rayap. Seperti terdapat pada (gambar 1).

Terjadinya gejala demikian disebabkan oleh nematoda $S$. carpocapsae yang telah masuk kedalam bagian pencernaan tubuh serangga uji $C$. curvignathus dan memakan bagian tubuh organ dalamnya. Waktu kematian C. curvignathus yang lebih cepat dikarenakan adanya bakteri Xenorhabdus yang bersimbiosis dengan nematoda sehingga bagian organ tubuh $C$. curvignathus menjadi hancur dan berbau busuk.

Simoes dan Rosa (1996), menyatakan bahwa $C$. curvignathus yang mati akibat $S$. carpocapsae bagian kutikulanya menjadi transparan setelah lebih dari 48 jam terinfeksi $S$. carpocapsae. Kematian yang terjadi karena aktivitas enzimatis bakteri Xenorhabdus yang menyebabkan hancurnya jaringan tubuh serangga uji menjadi lunak berair dan lama-lama akan hancur.

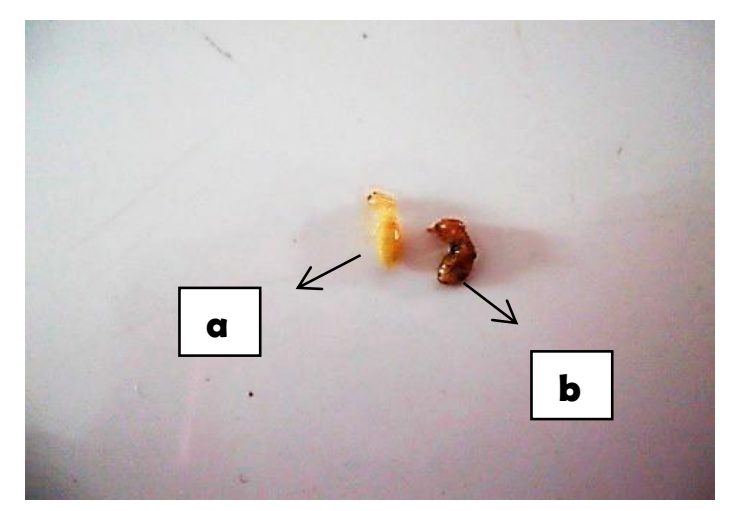

Gambar 1. Perbedaan warna tubuh C. curvignathus yang sehat dan terinfeksi NPS (a). Tubuh C.curvignathus sehat (b). Tubuh C. curvignathus yang terinfeksi NPS

\section{Mortalitas Coptotermes curvignathus Holmgren akibat infeksi Steinernema carpocapsae}

Daya mortalitas $C$. curvignathus akibat infeksi S. carpocapsae dengan berbagai konsentrasi terhadap serangga uji dapat dilihat pada (gambar 2). Data yang diperoleh berdasarkan uji patogenisitas nematoda patogen serangga (S. carpocasae) terhadap rayap tanah (C. curvignathus) menunjukan bahwa NPS (S. carpocasae) mampu menyebabkan mortalitas pada serangga uji. Hal ini ditunjukan dengan adanya persentase mortalitas C. curvignathus pada tiap konsentrasi nematoda patogen serangga. Pada konsentrasi $800 \mathrm{Ji} / \mathrm{ml}$ tingkat mortalitas $C$. curvignathus mencapai $100 \%$, sedangkan pada konsentrasi $25 \mathrm{Ji} / \mathrm{ml}$ menyebabkan mortalitas sebesar $19,00 \%$. 


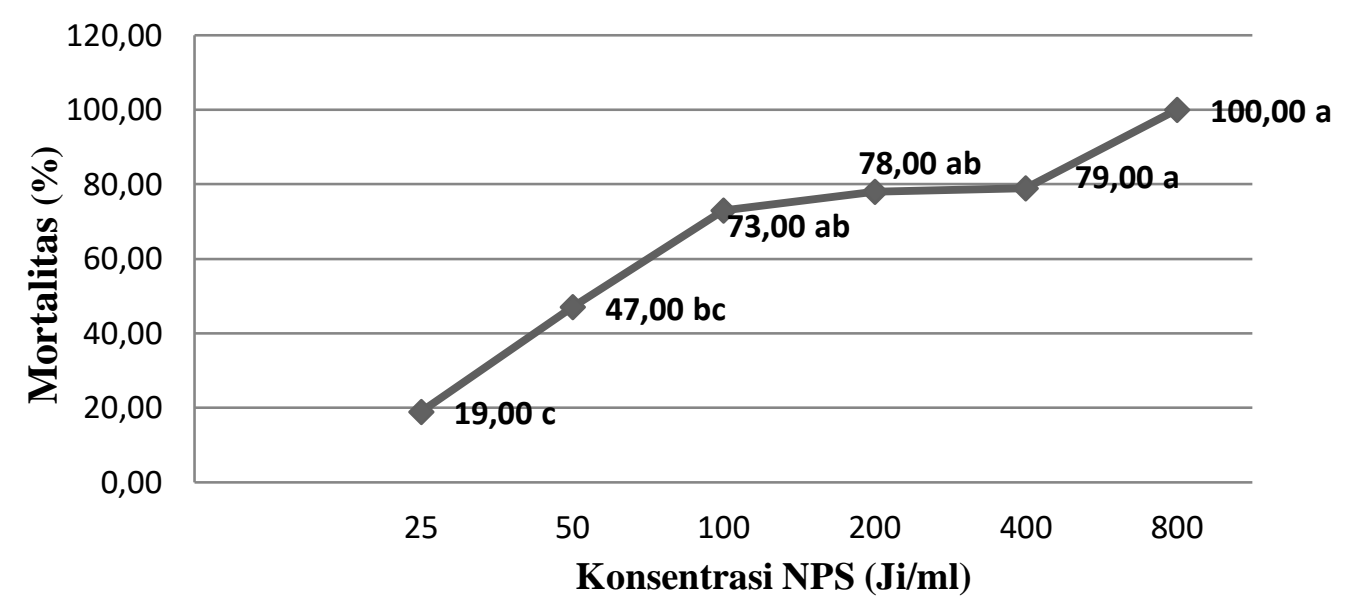

Gambar 2. Mortalitas C. curvignathus akibat infeksi S. carpocapsae dari tanah gambut jam ke-96 setelah inokulasi

Perbedaan persentase mortalitas $C$. curvignathus disebabkan adanya pengaruh tingkat kepadatan NPS yang diinokulasikan, sehingga dapat mempengaruhi mekanisme dan kecepatan S. carpocapsae dalam menginfeksi serangga uji C. curvignathus. Hasil ini sesuai dengan yang sudah dihasilkan oleh Djamilah (2011), yaitu semakin tinggi tingkat kepadatan NPS yang diinokulasikan maka dapat menyebabkan tingkat mortalitas serangga uji semakin tinggi. Tingginya tingkat kepadatan NPS yang diinokulasikan memungkinkan semakin banyak $S$. carpocapsae yang dapat menemukan inang dan penetrasi dalam tubuh C. curvignathus. Serangga uji yang aktif bergerak mempermudah $S$. carpocapsae dalam proses kontak dengan inang.

Hasil penelitian menunjukan adanya korelasi yang positif antara peningkatan konsentrasi NPS dengan daya mortalitas $C$. curvignathus. Korelasi mencapai angka 0,63 yang berarti bahwa korelasi kuat. Korelasi yang kuat ditandai dengan adanya tingkat mortalitas mencapai $100 \%$ pada konsentrasi $800 \mathrm{ji} / \mathrm{ml}$ dengan priode letal 40,68 dan virulensi 0.024 .

Mortalitas tinggi disebabkan juga oleh bakteri simbion yang ada didalam tubuh $S$. carpocapsae. Sebagaimana menurut Strauch dan Ehlers, (1998) menyatakan terhambatnya bakteri simbion akan memperlambat proses kematian serangga inangnya dan menghambat perkembangan $S$. carpocapsae, karena tanpa adanya bakteri simbion $S$. carpocapsae tidak akan berkembang dengan baik, demikian pula sebaliknya.

Fungsi bakteri simbion bagi $S$. carpocapsae adalah ; (1) membunuh inang dengan cepat (24-48 jam), (2) membuat suasana lingkungan yang cocok bagi perkembangan $S$. carpocapsae dengan memproduksi antibiotik yang dapat menghambat mikroorganisme sekunder, dan (3) menyediakan sumber nutrisi yang siap pakai untuk S. carpocapsae. Sedangkan fungsi S. carpocapsae bagi bakteri adalah melindungi bakteri dari lingkungan eksternal yang merugikan dan kemungkinan adanya toksin yang dikeluarkan oleh serangga inang (protein anti bakteri) (Kaya dan Gaugler, 1993 dalam Ehlers dan Peters, 1995).

Gambar 2 juga dapat dilihat bahwasanya penggunaan $S$. carpocapsae dalam meyebabkan mortalitas C. curvignathus memberikan pengaruh yang nyata. Rerata mortalitas $C$. curvignathus yang ditimbulkan sebesar $19,00 \%$ sampai $100 \%$. Hasil uji Duncan menunjukan bahwa konsentrasi 800 $\mathrm{ji} / \mathrm{ml}$ sangat berbeda nyata dengan perlakuan $25 \mathrm{ji} / \mathrm{ml}$ dan $50 \mathrm{ji} / \mathrm{ml}$. Namun tidak berbeda 
nyata dengan perlakuan $400 \mathrm{ji} / \mathrm{ml}, 200 \mathrm{ji} / \mathrm{ml}$ dan $100 \mathrm{ji} / \mathrm{ml}$.

Tingkat kepadatan S. carpocapsae yang diinokulasikan berbanding lurus dengan mortalitas serangga uji yang dihasilkan. Semakin tinggi tingkat kepadatan $S$. carpocapsae yang diinokulasikan maka mortalitas serangga uji juga semakin tinggi dan kemungkinan $S$. carpocapsae untuk dapat masuk dalam menginfeksi serangga ujinya juga lebih cepat.
Waktu kematian Coptotermes
Holmgren akibat infeksi
carpocapsae
Wakteinernemathus
Waktu kematian $\quad$ C. berhubungan dengan tingkat kepadatan $S$. carpocapsae yang diinokulasikan. Hasil yang diperoleh dalam penelitian menunjukan korelasi yang positif antara tingkat kepadatan S. carpocapsae yang diinokulasikan dengan kecepatan kematian serangga uji $C$. Curvignathus (tabel 1).

Tabel 1. Periode letal dan Virulensi S. carpocapsae dalam menginfeksi $C$. curvignathus

\begin{tabular}{ccc}
\hline Konsentrasi & Periode letal (jam) & Virulensi (jam) \\
\hline $25 \mathrm{Ji} / \mathrm{ml}$ & 56,21 & 0,017 \\
$50 \mathrm{Ji} / \mathrm{ml}$ & 46,72 & 0,021 \\
$100 \mathrm{Ji} / \mathrm{ml}$ & 48,32 & 0,020 \\
$200 \mathrm{Ji} / \mathrm{ml}$ & 47,23 & 0,021 \\
$400 \mathrm{Ji} / \mathrm{ml}$ & 38,43 & 0,026 \\
$800 \mathrm{Ji} / \mathrm{ml}$ & 40,68 & 0,024 \\
\hline
\end{tabular}

Berdasarkan tabel 1 dapat dilihat bahwasanya waktu kematian tertinggi terjadi pada perlakuan $400 \mathrm{ji} / \mathrm{ml}$ dan $800 \mathrm{ji} / \mathrm{ml}$ dengan priode letal $38,43-40,68$ dan virulensinya 0,026-0,024. Ini berarti dalam waktu 38-40 jam $S$. carpocapsae sudah mampu menyebabkan kematian pada serangga uji. Kematian yang begitu cepat dimungkinkan karena S. carpocapsae masuk melalui mulut saat proses memakan jaringan selulosa yang telah diinokulasikan S. carpocapsae.

S. carpocapsae masuk ke dalam pencernaan serangga uji dan menginfeksi saluran pencernaannya. Proses infeksi saluran pencernaan dibantu oleh bakteri simbionnya yang dapat mematikan serangga uji relatif lebih singkat. Proses kematian serangga uji yang demikian menjadikan $S$. carpocapsae sebagai nematoda yang bersifat patogenik. Tubuh serangga uji yang terserang akan hancur dalam 3-4 hari setelah inokulasi. Sebagaimana menurut Wagiman dkk, (2003), kematian serangga sasaran akibat infeksi nematoda melalui mulut dapat menyebabkan kematian pada hari kedua setelah inokulasi. Infeksi melalui kulit menyebabkan kematian pada hari kelima setelah inokulasi. Hal ini berarti infeksi melalui mulut jauh lebih cepat membunuh serangga uji dibandingkan melalui kulit.

Kematian serangga uji yang lebih cepat menunjukan adanya korelasi antara tingkat kepadatan yang diinokulasikan dengan waktu kematian yang dihasilkan. Tingkat korelasi tertinggi terjadi antara tingkat kepadatan $S$. carpocapsae dengan virulensi. Korelasi yang terjadi dengan nilai 0,73 yang berarti bahwa korelasi kuat. Tingginya tingkat korelasi dikarenakan NPS yang digunakan merupakan stadia juvenil infektif 3. Stadia juvenil infektif merupakan fase dimana $S$. carpocapsae mempunyai kecendrungan aktif mencari inang untuk tetap melangsungkan hidupnya. Stadia juvenil infektif 1 dan 2 S. carpocapsae tidak makan dan bergantung sepenuhnya pada cadangan internal untuk sumber energinya. Sehingga perilaku juvenil infektif $3 S$. 
carpocapsae lebih aktif untuk menyerang inangnya (Adams \& Nguyen, 2002).

Hasil penelitian juga menunjukan adanya korelasi antara tingkat virulensi dengan daya mortalitas. Angka korelasi yang diperoleh yaitu 0,61 yang berarti korelasi kuat. Hal tersebut dimungkinkan karena $S$. carpocapsae memiliki daya infeksi yang tinggi terhadap serangga uji $C$. curviganthus. Sehingga dalam waktu 96 jam setelah proses inokulasi $S$. carpocapsae mampu menyebabkan kematian serangga uji $100 \%$ pada perlakuan $800 \mathrm{ji} / \mathrm{ml}$.

\section{Jumlah NPS yang keluar dari dalam tubuh Coptotermes curvignathus Holmgren}

Jumlah NPS yang keluar dari tubuh serangga uji $C$. curvignathus diamati setiap 12 jam sekali dan dihitung setelah dilakukan proses white trap. Rerata $S$. carpocapsae per individu yang keluar dari tubuh $C$. curvignathus dapat dilihat pada tabel 2 berikut.

Tabel 2. Rerata S. carpocapsae per individu C. curvignathus kasta pekerja yang terinfeksi NPS dari tanah gambut

\begin{tabular}{|c|c|c|c|c|c|c|c|}
\hline \multirow{2}{*}{ Perlakuan } & \multicolumn{5}{|c|}{ Ulangan $(20 \mathrm{ml})$} & \multirow{2}{*}{ Total } & \multirow{2}{*}{$\begin{array}{c}\text { Rerata/ } \\
\text { Ekor }\end{array}$} \\
\hline & 1 & 2 & 3 & 4 & 5 & & \\
\hline $25 \mathrm{Ji} / \mathrm{ml}$ & 6716 & 1808 & 64 & 3746 & 0 & 12334 & $129,60 \mathrm{a}$ \\
\hline $50 \mathrm{Ji} / \mathrm{ml}$ & 0 & 0 & 17967 & 3455 & 7323 & 28744 & $122,40 \mathrm{a}$ \\
\hline $100 \mathrm{Ji} / \mathrm{ml}$ & 27542 & 5758 & 8540 & 10521 & 9883 & 62244 & $170,40 \mathrm{a}$ \\
\hline $200 \mathrm{Ji} / \mathrm{ml}$ & 11006 & 10184 & 11184 & 16007 & 8957 & 57338 & $147,00 \mathrm{a}$ \\
\hline $400 \mathrm{Ji} / \mathrm{ml}$ & 16679 & 1704 & 6821 & 19758 & 16278 & 61239 & $155,00 \mathrm{a}$ \\
\hline $800 \mathrm{Ji} / \mathrm{ml}$ & 16189 & 12406 & 7291 & 24101 & 20160 & 80147 & $160,40 \mathrm{a}$ \\
\hline
\end{tabular}

Tabel 2 menunjukan data rerata individu $S$. carpocapsae yang keluar dari tubuh $C$. curvignathus tidak berbeda antara satu perlakuan dengan perlakuan lainnya. Tingkat kepadatan, mortalitas dan waktu kematian serangga uji yang cepat tidak memberikan pengaruh yang nyata terhadap jumlah $S$. carpocapsae yang keluar dari tubuh $C$. curvignathus.

Jumlah S. carpocapsae yang keluar cenderung sama antara satu perlakuan dengan perlakuan lainnya. Rerata jumlah S. carpocapsae yang dihasilkan berkisar antara 122-170 ekor dalam tiap tubuh serangga uji. Hal tersebut terjadi karena tidak semua $S$. carpocapsae yang diinokulasikan mampu untuk masuk dan menginfeksi organ tubuh $C$. curvignathus. Terjadinya kompetisi dalam mendapatkan makanan, hal ini terlihat pada pengamatan yang dilakukan pada media uji yang digunakan juga banyak ditemukan $S$. carpocapsae. Sebagaimana menurut Kaya dan Koppenhofer, (1999) yang menyatakan bahwa terjadinya perbedaan jumlah NPS yang keluar disebabkan adanya kompetisi dalam hal ruang dan makanan antara nematoda itu sendiri, sehingga proses infeksi keserangga inang tidak optimal. Selain itu, yang mempengaruhi jumlah NPS yang keluar perindividu $C$. curvignathus yaitu ukuran tubuh $C$. curvignathus yang sangat kecil menyebabkan tidak semua NPS yang diinokulasikan mampu masuk kedalam tubuh $C$. curvignathus.

Hasil uji Duncan rerata individu NPS yang keluar dari tubuh $C$. curvignathus menunjukan tidak berbeda nyata antara perlakuan $25 \mathrm{Ji} / \mathrm{mL}, 50 \mathrm{Ji} / \mathrm{mL}, 100 \mathrm{Ji} / \mathrm{mL}, 200$ $\mathrm{Ji} / \mathrm{mL}, 400 \mathrm{Ji} / \mathrm{mL}$, dan $800 \mathrm{Ji} / \mathrm{mL}$. Ini berarti bahwa setiap individu C. curvignathus memiliki kapasitas ruang yang sama bagi perkembangan $S$. carpocapsae. Seberapa besarpun tingkat kepadatan $S$. carpocapsae yang diinokulasikan maka tidak akan berpengaruh terhadap jumlah nematoda yang dihasilkan dari tiap individu tubuh $C$. curvignathus. Mortalitas dan waktu kematian 
yang lebih cepat tidak memberikan pengaruh yang signifikan bagi perkembangan $S$. carpocapsae dalam tubuh $C$. curvignathus.

C. curvignathus kasta pekerja merupakan kasta yang sebagian besar pembentuk koloni rayap. Kasta ini memiliki ukuran tubuh 4,5-5,0 $\mathrm{mm}$ dengan lebar kepala 1,4-1,5 mm (Borror dkk, 1992). Ukuran tubuh rayap yang kecil menyebabkan berkurangnya ruang kapasitas $S$. carpocapsae untuk memperbanyak diri. Oleh sebab itu dalam penelitian ini $S$. carpocapsae yang dihasilkan tidak berbeda nyata antara satu perlakuan dengan perlakuan lainnya. Selain itu, dimungkinkan karena faktor suhu dan temperatur yang cocok untuk perkembangan $S$. carpocapsae.

\section{KESIMPULAN}

Berdasarkan hasil uji patogenisitas $S$. carpocapsae terhadap C. curvignathus dari tanah gambut dapat disimpulkan bahwa isolat S. carpocapsae dari tanah gambut mempunyai patogenisitas yang baik terhadap rayap tanah (C. curvignathus). Patogenisitas tertinggi terjadi pada perlakuan $800 \mathrm{Ji} / \mathrm{ml}$ dengan tingkat mortalitas mencapai $100 \%$ dengan priode letal 40,68 dan virulensi 0,024 pada jam ke-96 kematian. Konsentrasi $25 \mathrm{ji} / \mathrm{ml}$ menyebabkan kematian 19\% dengan priode letal 56,21 dan virulensi 0,017 pada jam ke-96 setelah proses inokulasi. Gejala $C$. curvignathus yang terinfeksi $S$. carpocapsae ditandai dengan gerakannya menjadi lambat, tubuhnya lembek, abdomennya bengkak, perubahan warna tubuh, dan akhirnya tubuh hancur.

\section{DAFTAR PUSTAKA}

Adams, B.J. \& K.B. Nguyen, 2002. Taxonomy and Systematics In Gaugler, R (Ed.) Entomopathogenic Nematology. Wallingford, UK. CABY Publishing. Pp. 1-33.
Borror, 1992. Pengenalan Pelajaran Serangga, edisi VI. Gajah Mada University Press.Yogyakarta.

Djamilah, 2011. Patogenisitas Steinernema sp. Isolat Bengkulu Terhadap Rayap (Coptotermes curvignathus Holmgren). Fakultas Pertanian, Universitas Bengkulu. Manggaro, 12(1):39-43.

Ehlers, R.U \& T.A. Peters, 1995. Entomopatogenic Nematodes In Biological Control Feasibility, Perspective and Possible Risk. Pp. 119-136. In : M, M, T, Hokkanen and J. M. Lynch. Eds, Biological Control : Benefits and Risk. Dambridge University Press, Cambridge.

Gaugler, R. \& H.K Kaya, 1990. Entomopathogenic Nematodes in Biological Control. Florida: CRC Press. Boca Raton.

Kaya, H.K. \& A.M. Koppenhofer, 1999. Biology and Ecology of Insecticidal Nematodes. In. Workshop Proceedings: Optimal Use of Insecticidal Nematodes in Pest Managemen. Edited by S. Polavarapu. Rutgers University. pp.1-8.

Kaya, H.K. \& R. Gaugler. 1993. Entomopathogenic nematodes. Annu. Rev.Entomol. 38: 181-206

Mahardika, D., 2001. Seminar Rayap.http://www.pu.go.id/publikproduk/ seminar/kolo kium 2001/kolokium 2001 07.pdf

Ridwanti, B., 2002. Biologi Serangga Penggerek Kayu. http://www. deptan.go.id/ditlihori/0408/18/ilpeng/120 9399,htm. Diakses 11 Febuari 2015.

Rosmana A, S.S. Alias, \& Sjamsiar, 1998. Evaluasi penggunaan nematoda entomopatogen Steinernema carpocapsae isolat Sulawesi Selatan sebagai biosida untuk mengendalikan hama kubis Crocidolomia binotalis. Skripsi. Fak. Pertanian dan Kehutanan, Universitas Hasanuddin, Ujung Pandang. Tidak dipublikasikan. 
Simoes, N. \& J.S. Rosa, 1996. Pathogenicity and Host Specificity of Enthomophathogenic Nematoda. J.Invert. Pathol. (6):403-411

Strauch, O., \& R. U. Ehlers, 1998. Food Signal Production of Photorhabdus luminescens Inducing the Recovery of Entomopathogenic Nematodes Heterorhabditis spp. on Liquid culture. Applied Microbiology and Biotechnology. 50: 369-374..

Susilo, F.X.,Hasibuan, R.,Nordin, G.L. \& G.C. Brown, 1993. The concept of threshold density in insect pathologi: A Theoritical and Experimental study on TetranychusNeozygites mycosis. Prosiding makalah simposium patologi serangga. Yogyakarta, 12-13 Oktober 1993. Pp. 2937

Tanada Y. \& H. K. Kaya, 1993. Insect Pathology. Academic Press Inc, London.

Wagiman, F.X.,B. Triman, dan Rr.S. Astuti. 2003. Keefektifan Steinernema spp. Terhadap Spodoptera exigua. Jurnal Perlindungan Tanaman Indonesia (9): $22 ; 27$ 